\title{
Pengaruh ekspor, utang luar negeri, neraca transaksi berjalan dan neraca transaksi modal terhadap cadangan devisa di Indonesia
}

\author{
Graselita Aritonang*; Amril; Zulgani
}

\author{
Prodi Ekonomi Pembangunan, Fak. Ekonomi dan Bisnis, Universitas Jambi \\ *E-mail korespondensi: aritonanggraselita@gmail.com
}

\begin{abstract}
The purpose of this study is to (1) see the description of Indonesia's foreign exchange reserves, exports, foreign debt, current account balance, and capital account balance for the period 1998-2017. (2) analyze the effect of exports, foreign debt, current account balance, and capital account balance on Indonesia's foreign exchange reserves. The method used in this research is quantitative descriptive analysis with multiple regression model analysis using the Ordinary Least Square (OLS) method. The results of this study show that the average development of Indonesia's foreign exchange reserves is 11.87 percent, exports are 7.38 percent, foreign debt is 4.51 percent, the current account balance is 514.89 percent and the capital account balance is 66.92 percent. Based on the results of the analysis carried out by exports, foreign debt, current account balance, and capital account have a positive and significant effect on foreign exchange reserves with a coefficient of determination of 98.37 percent.
\end{abstract}

Keywords: Foreign exchange, export, Foreign debt, Current account, Capital account

\begin{abstract}
Abstrak
Tujuan penelitian ini untuk (1) Melihat gambaran cadangan devisa Indonesia, ekspor, utang luar negeri, neraca transaksi berjalan dan neraca transaksi modal periode 19982017. (2) menganalisis pengaruh ekspor, utang luar negeri, neraca transaksi berjalan dan neraca transaksi modal terhadap cadangan devisa Indonesia. Metode yang digunakan dalam penelitian ini adalah analisis deskriptif kuantitatif dengan alat analisis model regresi berganda dengan metode Ordinary Least Square (OLS). Hasil penelitian ini ratarata perkembangan cadangan devisa Indonesia sebesar 11,87 persen, ekspor sebesar 7,38 persen, utang luar negeri sebesar 4,51 persen, neraca transaksi berjalan sebesar 514,89 persen dan neraca transaksi modal sebesar 66,92 persen. Berdasarkan hasil analisis yang dilakukan Ekspor, utang luar negeri, neraca transaksi berjalan dan neraca transaksi modal berpengaruh secara positif dan signifikan terhadap cadangan devisa dengan koefisien determinasi sebesar 98,37 persen.
\end{abstract}

Kata kunci: Cadangan devisa, Ekspor, Utang luar negeri, Neraca transaksi berjalan, Neraca transaksi modal

\section{PENDAHULUAN}

Indonesia adalah negara yang berkembang, dimana Indonesia terus melakukan perubahan diberbagai bidang untuk mencapai masyarakat adil dan makmur. Salah satu sumber dari pembangunan tersebut diperoleh dari cadangan devisa negara. Cadangan devisa adalah alat yang bisa dipergunakan untuk transaksi pembayaran dengan luar 
negeri. Cadangan devisa negara diperoleh dari perdagangan antar negara dengan kegiatan ekspor, dan bisa melihat seberapa mampu suatu negara bisa melakukan perdagangan. Sumber cadangan devisa Indonesia yang begitu melimpah ruah bisa diperdagangkan ke luar negeri (Hariyani dkk, 2010). Cadangan devisa bagi suatu negara mempunyai tujuan dan manfaat seperti halnya manfaat kekayaan bagi suatu individu (Gandhi, 2006). Selain itu, jumlah cadangan devisa dalam jumlah yang cukup merupakan salah satu jaminan untuk tercapainya stabilitas moneter dan ekonomi makro suatu Negara (Priadi dkk, 2008).

Mengingat pentingnya peran cadangan devisa dalam pembiayaan pembangunan suatu negara, maka setiap negara berusaha untuk mempertahankan posisi cadangan devisa yang dimiliki, bahkan berusaha untuk meningkatkannya. Salah satu cara yang dilakukan untuk memperoleh tambahan cadangan devisa adalah melalui kegiatan perdagangan khususnya ekspor (Suryaningsih, 2007). Pengelolaan dan pemeliharaan cadangan devisa didasarkan pada prinsip untuk memperoleh pendapatan yang optimal. Beberapa faktor lain yang mempengaruhi cadangan devisa diantaranya adalah ekspor, utang luar negeri, neraca transaksi berjalan dan transaksi modal. Dalam menciptakan daya saing maka perbaikan mutu standar komodisi ekspor perlu ditingkatkan sehingga dapat menhindari adanya penolakan (klaim) dari pembeli luar negeri (importir). Utang luar negeri dapat menambah cadangan devisa, yang awalnya dalam bentuk pinjaman yang dapat memperkuat cadangan devisa. Apabila utang luar negeri diinvestasikan secara produktif maka akan menghasilkan tingkat pengembalian devisa yang tinggi. Neraca transaksi berjalan digunakan untuk menilai neraca perdagangan. Neraca perdagangan merupakan selisih atau perbedaan antara ekspor dan impor. Jika impor lebih tinggi dari ekspor, maka yang terjadi adalah defisit neraca perdagngan . Sebaliknya, jika ekspor lebih tinggi dan impor yang terjadi adalah surplus. Dengan begitu defisit neraca transaksi berjalan dapat diatasi salah satunya dengan cara meningkatkan ekspor dan mengurangi jumlah ekspor dan akan berakibat kepada cadangan devisa yang meningkat pula.

Cadangan devisa tentunya menjadi suatu indikator yang kuat untuk melihat sejauh mana suatu negara mampu melakukan perdagangan dan menunjukkan perekonomian negara tersebut. Seiring perkembangan pemerintah sebagai otoritas pemberlaku kebijakan sertapelaku gerak pertumbuhan ekonomi dalam negeri, pendanaan tersebut didominasi atas utang luar negeri, yang dianggap sebagai masukan pendapatan saat itu bagi pemerintah. Cadangan devisa juga merupakan kunci utama agar dapat terhindar dari krisis (Priadi, 2008). Kelebihan cadangan devisa juga memiliki peran penting dalam mengurangi fluktuasi nilai tukar dan mendorong kemajuan ekonomi suatu Negara. Posisi cadangan devisa suatu negar biasanya dinyatakan aman apabila mencukupi kebutuhan impor untuk jangka waktu setidaktidaknya tiga bulan,jika cadangan devisa yang dimiliki suatu negara tidak mencukupi kebutuhan untuk tiga bulan impor,maka kondisi tersebut dianggap rawan (Wira, 2014).

\section{METODE}

Dalam penelitian ini penulis menggunakan penelitian deskriptif kuantitatif. Data yang digunakan dalam penelitian ini merupakan data sekunder yang merupakan data berkala dari tahun 1998-2017. Data yang digunakan dalam penelitian ini bersumber dari Asian Development Bank, Bank Indonesia dan Badan Pusat Statistik Indonesia.

\section{Analisis Deskriptif}


Analisis deskriptif adalah statistik yang digunakan untuk menganalisis data dengan cara mendeskripsikan atau menggambarkan data yang telah terkumpul sebagaimana adanya tanpa bermaksud membuat kesimpulan yang berlaku untuk umum atau generalisasi (Sugiyono, 2015). Analisis ini hanya merumuskan dan menyimpulkan data yaitu dengan cara membuka atau melihat data tabulasi yang ada dan menganalisisnya. Untuk menganalisis data digunakan rumus sebagai berikut :

$$
\mathrm{G}_{\mathrm{X}}=\frac{\mathrm{X}_{\mathrm{t}}-\mathrm{X}_{\mathrm{t}-1}}{\mathrm{X}_{\mathrm{t}-1}} \times 100 \%
$$

Dimana :

$\mathrm{Gx}$ = Laju perkembangan $\mathrm{X}$

$\mathrm{X}_{\mathrm{t}} \quad=$ Data $\mathrm{x}$ tahun tertentu

$\mathrm{X}_{\mathrm{t}-1}=$ Data $\mathrm{x}$ tahun sebelumnya

\section{Analisis kuantitatif}

Analisis kuantitatif adalah analisis yang dilakukan dengan cara menguji dan mengumpulkan data untuk menguji pengaruh antara variabel bebas terhadap variabel terikat. Alat ini digunakan untuk melihat secara empiris sejauh mana pengaruh variabel bebas terhadap variabel terikat yang terpilih. Berkaitan dengan penelitian yang dilakukan untuk melihat pengaruh ekspor, utang luar negeri, neraca transaksi berjalan dan neraca transaksi modal terhadap Cadangan devisa yang menggunakan alat analisis regresi linear berganda dengan metode Ordinary Least Square (OLS). Model persamaannya adalah sebagai berikut (Kuncoro, 2009) :

$$
\begin{gathered}
Y_{t}=\beta+\beta 1 X 1_{t}+\beta 2 X 2_{t}+\beta 3 X 3_{t}+\beta 4 X 4_{t}+\epsilon_{t} \\
C D_{t}=\beta 0+\beta 1 E X_{t}+\beta 2 U N_{t}+\beta 3 N T B_{t}+\beta 4 T M L_{t}+\epsilon_{t}
\end{gathered}
$$

Dimana : $\mathrm{CD} \quad=$ Cadangan devisa

BO $\quad=$ Konstanta

EX $\quad=$ Ekspor

ULN = Utang luar negeri

NTB = Neraca transaksi berjalan

TML = Neraca transaksi modal

$\epsilon_{\mathrm{t}} \quad=$ Kesalahan penganggu diluar model

\section{HASIL DAN PEMBAHASAN}

\section{Perkembangan Cadangan Devisa}

Cadangan devisa memiliki peranan yang sangat penting dalam perekonomian suatu Negara. Cadangan devisa merupakan suatu indicator yang digunakan untuk melihat sejauh mana Negara tersebut mampu melakukan perdagangan dengan Negara lain. Rendahnya persediaan cadangan devisa suatu Negara maka akan berdampak pada sulitnya perekonomian Negara tersebut. Salah satu cara untuk menaikkan jumlah cadangan devisa adalah menggenjot ekspor dan mengurangi impor serta utang luar negeri. Cadangan devisa merupakan asset Negara yang dapat digunakan untuk keperluan mendesak. Rata-rata perkembangan cadangan devisa selama periode 19982017 adalah 11, 87 persen. Perkembangan nilai cadangan devisa tertinggi terjadi pada tahun 1999 dan perkembangan terendah terjadi pada tahun 2013. 


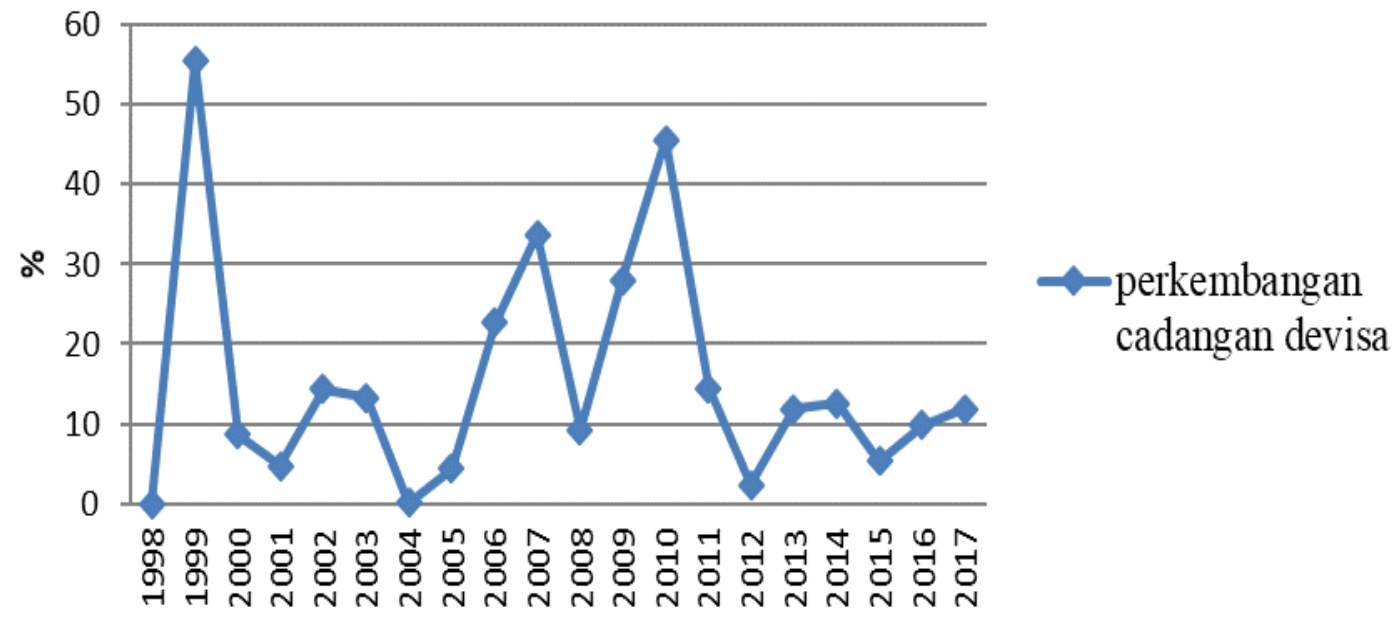

Sumber : Bank Indonesia, 2019(diolah)

Gambar 1. Perkembangan cadangan devisa

Perkembangan cadangan devisa di Indonesia periode 1998-2017 cenderung mengalami fluktuasi dari tahun ke tahun. Rata-rata perkembangan cadangan devisa Indonesia adalah 11,87 persen. Perkembangan tertinggi terjadi pada tahun 1999 yaitu sebesar 55,48 persen disebabkan oleh membaiknya kurs rupiah yang pernah mencapai kurs terendah akibat krisis ekonomi di tahun 1998. Perkembangan terendah terjadi pada tahun 2013 yaitu sebesar -11,88 persen penurunan ini diakibatkan oleh meningkatnya kegiatan impor serta peningkatan permintaan terhadap valuta asing domestic.

\section{Perkembangan ekspor}

Dalam perdagangan nternasional ekspor merupakan kegiatan penting, dimana ekspor adalah kegiatan menjual barang ke luar negeri dengan menggunakan pembayaran, kualitas, kuantitas dan syarat penjualan lain yang disetujui oleh eksportir dan importer. Agar mampu mengekspor, suatu Negara harus berupaya menhasilkan barang dan jasa yang mampu bersaing di pasar internasional (Sonia dkk, 2016)

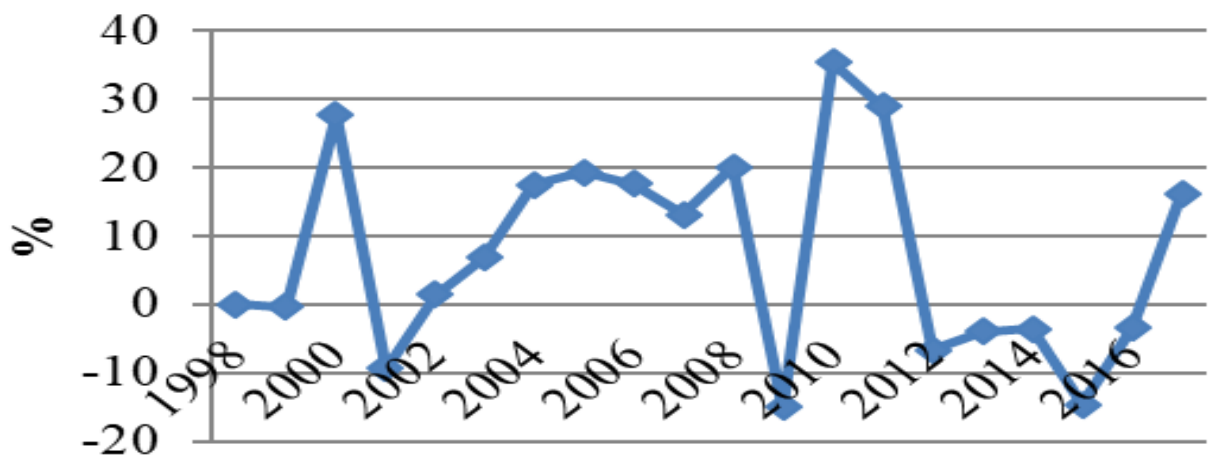

Sumber :BPS, 2019(diolah)

Gambar 2. Perkembangan ekspor

Perkembangan ekspor Indonesia mengalami fluktuasi dari tahun ke tahun. Perkembangan tertinggi terjadi pada tahun 2010 yaitu sebesar 35,42 persen kenaikan ekspor ini disebabkan oleh peningkatan harga komoditas, meskipun kenaikan volume ekspor juga terjadi diberbagai komoditas. Namun demikian, kenaikan volumeyang 
tejadi cenderung belum merata dan masih terkonsentrasi pada komoditas sumber daya alam (SDA), khususnya pertambangan. Perkembangan terendah terjadi pada tahun 2009 yaitu sebesar -14,97 persen akibat melemahnya harga dan volume sejumlah komoditi andalan Indonesia di pasar dunia sementara rata-rata perkembangan Ekspor adalah sebesar 7,38 persen.

\section{Perkembangan utang luar negeri}

Sebagai Negara berkembang yang sedang membangun yang memiliki cirri-ciri dan persoalan ekonomi, poitik, sosial dan budaya hampir sama dengan Negara berkembang lainnya Indonesia tidak dapat terlepas dari masalah utang luar negeri dalam kurun waktu 20 tahun terakhir, utang luar negeri telah memberikan sumbangannya yang cukup besar bagi pembangunan Indonesia. Bahkan utang luar negeri telah menjadi sumber utama untuk menutupi defisit Anggaran Pendapatan Belanja Negara (APBN) dan memberikan kontribusi bagi pertumbuhan Produk Domestik Bruto (PDB) yang akhirnya dapat meningkatkan pertumbuhan ekonomi.

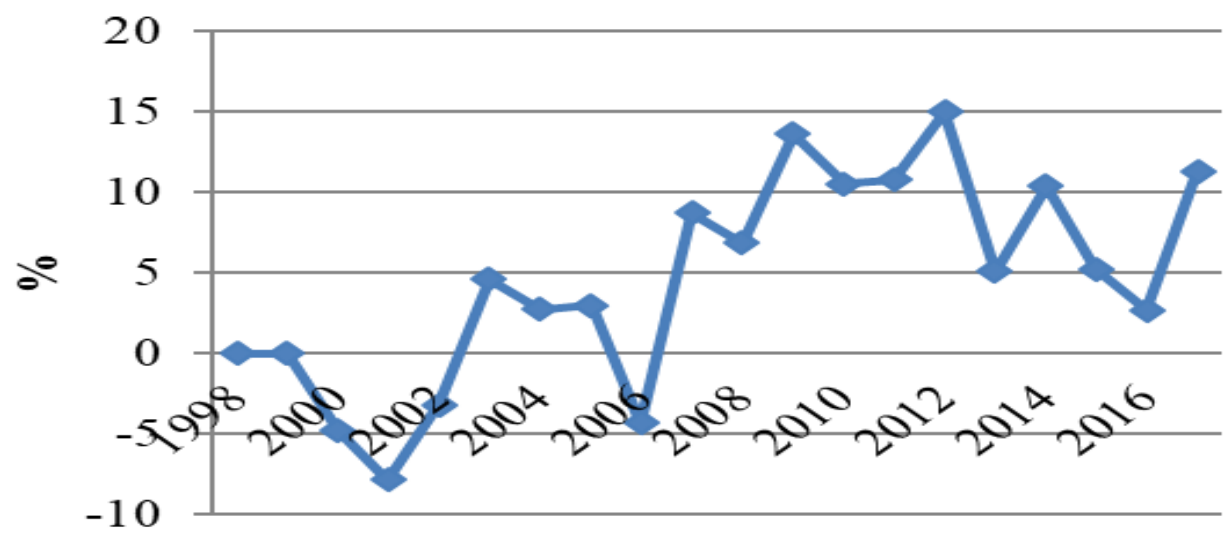

Sumber : Bank Indonesia, 2019(diolah)

Gambar 3. Perkembangan utang luar negeri

Perkembangan utang luar negeri Indonesia mengalami fluktuasi dan cenderung meningkat dari tahun ke tahun, perkembangan tertinggi terjadi pada tahun 2012 yaitu sebesar 15 persen diakibatkan defisit anggaran yang berarti penerimaan Negara lebih kecil dibandingkan anggaran yang harus dibelanjakan. Kecilnya penerimaan Negara diperngaruhi banyak factor mulai dari lesunya ekspor dan impor hingga penerimaan pajak.. Perkembangan terendah terjadi pada tahun 2001 yaitu sebesar 7,87 persen dikarenakan upaya pemerintah dalam menstabilkan nilai rupiah dan perekonomian agar tidak terulang kembali krisis yang terjadi di tahun 1997, terutama dipengaruhi oleh transaksi pembayaran neto utang luar negeri dan pelemahan nilai tukar rupiah terhadap dolar AS sehingga utang dalam rupiah tercatat lebih rendah dalam denominasi dolar AS. Rata-rata perkembangan utang luar negeri Indonesia adalah sebesar 4,51 persen.

\section{Perkembangan neraca transaksi berjalan}

Nerca transaksi berjalan merupakan ukuran yang menunjukkan kinerja makro ekonomi suatu Negara. Neraca transaksi berjalan juga menunjukkan sumber dan penggunaan pendapatan nasional ekspor barang dan jasa disamping juga pendapatan dari investasi di luar negeri serta hibah merupakan sumber pendapatan nasional. Di sisi lain, penduduk dalam negeri dan pemerintah menggunakan pendapatannya untuk 
membeli barang-barang dari luar negeri, membri bantuuan serta membayar pendapatan investasi penduduk Negara lain ke luar negeri.

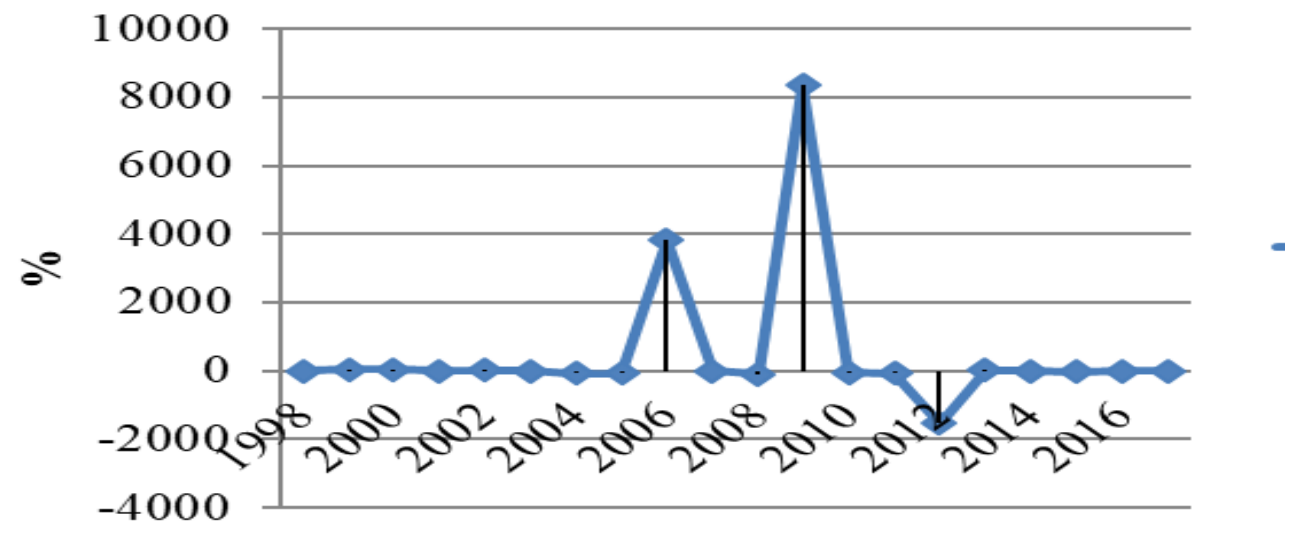

\section{Sumber: ADB, 2019(diolah)}

Gambar 4. Perkembangan neraca transaksi berjalan

Perkembangan Neraca Transaksi Berjalan Indonesia mengalami fluktuasi. Ratarata perkembangan neraca transaksi berjalan Indonesia adalah sebesar 514,89 persen. Perkembangan tertinggi terjadi pada tahun 2009 dimana perkembangan neraca transaksi berjalan Indonesia sebesar 8363,52 persen akibat dari perbaikan kinerja transaksi berjalan tersebut ditopang oleh meningkatnya surplus pada neraca perdagangan nonmigas, serta menyusutnya defisit pada neraca perdagangan minyak dan neraca jasa. Perkembangan terendah terjadi pada tahun 2012 dimana perkembangan neraca transaksi berjalan Indonesia sebesar 1549,08 persen dipicu oleh defisitnya neraca perdagangan migas, meningkatnya nilai impor yang dibarengi dengan turunnya kinerja ekspor sehingga membuat neraca berjalan mengalami defisit untuk pertama kalinya.

\section{Perkembangan neraca transaksi modal}

Neraca transaksi modal merupakan neraca yang menjadi andalan Indonesia dalam menutupi defisit pada neraca transaksi berjalan. Keseimbangan transaksi modal merupakan keseimbangan yang dihitung dari transaksi investasi jangka panjang, investasi jangka pendek, pemindahan emas dan transaksi pengangkatan mata uang. Neraca transaksi modal dinyatakan seimbang bila arus uang dan tabungan yang keluar sama besarnya fngan arus uang yang masuk dari transaksi-transaksi tersebut yang terjadi antarnegara.

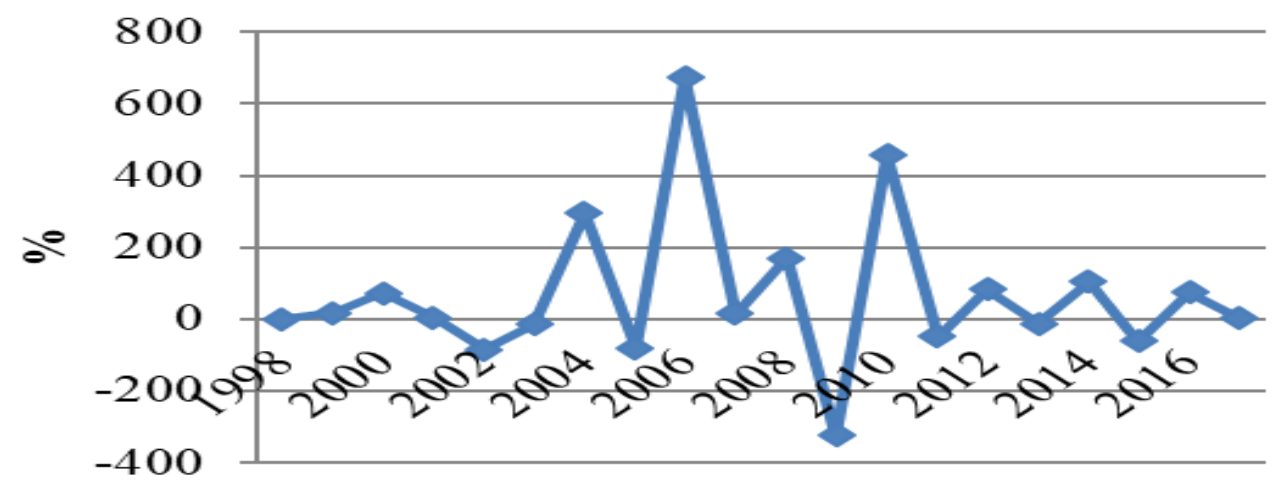

Sumber : $A D B, 2019$ (diolah)

Gambar 5. Perkembangan neraca transaksi modal 
Perkembangan neraca transaksi modal Indonesia mengalami fluktuasi. Rata-rata perkembangan neraca transaksi modal Indonesia adalah sebesar 66,92 persen. Perkembangan tertinggi terjadi pada tahun 2006 dimana sebesar 673,41 persen peningkatan ini disebabkan oleh membaiknya lalu lintas penanaman modal langsung sejalan dengan tngginya persetujuan penanaman modal asing (PMA), Perkembangan terendah terjadi pada tahun 2009 dimana perkembangan neraca transaksi berjalan Indoonesia sebesar 323,85 persen penurunan ini disebabkan oleh memburuknya pasar financial global, melambatya pertumbuhan ekonomi dunia dan turunnya harga komoditas global.

\section{Analisis kuantitatif}

Regresi linear berganda digunakan untuk melihat pengaruh ekspor, utang luar negeri, neraca transaksi berjalan dan neraca transaksi modal terhadap cadangan devisa di Indonesia. Berikut hasil dari metode analisis dan perhitungan yang dilakukan melalui program Eviews 10 diperoleh regresi sebagai berikut.

Tabel 1. Hasil analisis regresi berganda

\begin{tabular}{lcccc}
\hline \multicolumn{1}{c}{ Variable } & Coeffecient & Std.Error & t-statistic & Prob. \\
\hline C & -34586.15 & 7572.651 & -4.567246 & 0.0004 \\
EX & 0.352812 & 0.043672 & 8.078611 & 0.0000 \\
ULN & 0.289232 & 0.041071 & 7.042207 & 0.0000 \\
NTB & 0.576546 & 0.204052 & 3.201268 & 0.0059 \\
TML & 0.493690 & & 2.419431 & 0.0287 \\
R-Squared & 0.983774 & & Mean dependent var \\
Adjusted Rsquared & 0.979447 & & S.D dependent var \\
S.E. of regression & 5492.562 & & Akaike info criterion \\
Sum squared resid & $453 E+08$ & & Schwarz criterion \\
Log likelihood & -197.7250 & & Hannan-Quinn criter \\
F-statistic & 227.3565 & & Durbin-Watson stat \\
Prob(F-statistic) & 0.000000 & & \\
Suber : Data dion & \\
\hline
\end{tabular}

Sumber : Data diolah, 2019

Berdasarkan hasil regresi diatas, maka dapat diperoleh persamaan sebagai berikut:

$$
\mathrm{CD}_{\mathrm{t}}=-34586.15+0.3528 \mathrm{EX}+0.2892 \mathrm{ULN}+0.5765 \mathrm{ULN}+0.4936 \mathrm{TML}+e_{t}
$$

Hasil regresi diketahui bahwa Ekspor memiliki pengaruh yang signifikan terhadap cadangan devisa Indonesia periode 1998-2017 dengan asumsi variabel lain dianggap konstan. Koefisien regresi sebesar 0,352812 artinya jika Ekspor meningkat 1 juta US dolar maka Cadangan Devisa bertambah sebesar 0,352812 juta US dolar. Penelitian ini sejalan dengan penelitian yang dilakukan oleh suryaningsih pada tahun 2007 yang menyebutkan bahwa jika ekspor meningkat maka jumlah cadanga devisa yang dimiliki akan ikut meningkat sehingga persediaan impor dalam beberapa bulan berikutnya akan tercukupi dan akan memperbesar kemampuan Negara tersebut melakukan transaksi ekonomi.

Hasil regresi diketahui bahwa utang luar negeri berpengaruh signifikan terhadap cadangan devisa Indonesia selama periode 1998-2017 dengan asumsi variabel lain yang konstan. Koefisien regresi sebesar 0,2892 artinya jika utang luar negeri meningkat 1 juta US dollar maka cadangan devisa akan naik sebesar 0,2892 juta US dollar. Utang luar negeri memang dapat menambah cadangan devisa, yang awalnya berbentuk 
pinjaman yang dapat memperkuat cadangan devisa tetapi setiap pinjaman luar negeri yang diterima oleh Indonesia akan menambah akumulasi utang dan pada gilirannya akumulasi utang ini harus dibayar. Hasil ini sesuai dengan penelitian terdahulu yang dilakukan oleh Putra dkk pada tahun 2013. Melalui pembayaran utang yang mana pembayaran ini jelas mengambil cadangan devisa. Berdasarkan hasil regresi dapat diketahui bahwa koefisien regresi neraca transaksi berjalan sebesar 0,5765 artinya jika neraca transaksi berjalan meningkat 1 juta US dolar maka cadangan devisa akan naik sebesar 0,5765 juta US dolar, variabel neraca transaksi berjalan berpengaruh signifikan terhadap cadangan devisa Indonesia.

Penelitian ini sesuai dengan penelitian terdahulu yang dilakukan oleh Lucyana Leonufna dkk pada tahun 2016 dimana hasil yang diperoleh adalah neraca transaksi berjalan berpengaruh negative dan signifikan terhadap cadangan devisa Indonesia. Neraca transaksi berjalan mencatat pengeluaran dan penerimaan (ekspor dan impor) barang dan jasa bersama-sama dengan transfer neto. Transaksi ekspor dan impor barang meliputi sector pertanian, barang-barang produksi industry dan barang-barang yang diproduksi oleh sector pertambangan. Sedangkan transaksi ekspor dan impor jasa meliputi pembayaran biaya pengangkutan dan asuransi dari barang0barang yang diekspor atau diimpor. Neraca membuat transaksi ekspor dan impor jasa disebut dengan neraca jasa. Transaksi berjalan memberikan gambaran tentang nilai transaksi yang diakibatkan oleh kegiatan perdagangan barang dan jasa. Transasksi yang sedang berjalan mempinyai arti khusus apabila surplus transaksi berjalan neraca yang sedang berjalan menunjukkan bahwa ekspor lebih besar dari impor. Ini berarti bahwa suatu Negara mengalami akumulasi kekayaan valuta asing sehingga mempunyai saldo positif dalam investasi di luar negeri.

Dari hasil regresi diketahui bahwa koefisien regresi neraca transaksi modal sebesar 0,4936 artinya jika variabel neraca transaksi modal meningkat sebesar 1 juta US dollar maka cadangan devisa akan meningkat sebesar 0,4936 juta US dollar. Maka neraca transaksi modal berpengaruh signifikan terhadap cadangan devisa di Indonesia1sama seperti studi sebelumnya oleh Hanna pada tahun 2017. Pada saat investor Negara lain melakukan investasi di Indonesia yang berarti tercatat arus modal masuk dineraca transaksi modal Indonesia maka akan menyebabkan surflus transaksi modal Indonesia yang tentunya akan berdampak terhadap peningkatan neraca pembayaran Indonesia. Naiknya neraca pembayaram akan menambah asset luar negeri Indonesia sendiri. Asset luar negeri inilah yang akan menyebabkan cadangan devisa meningkat. Namun apabila terjadi penurunan neraca modal sehingga neraca pembayaran juga akan menurun.

Penurunan neraca pembayaran akan berdampak pada penurunan berbagai asset luar negeri sehingga cadangan devisa akan menurun. Pemerintah perlu menetapkan berbagai kebijakan dalam menstabilkan perekonomian Indonesia dengan tujuan untuk meningkatkan kepercayaan investor dengan melakukan investasi di Indonesia serta mengurangi investasi di Negara lain agar arus modal masuk lebih besar dari arus modal keluar. Salah satu kebijakan yang dapat dilakukan pemerintah untuk menarik investor yaitu menjaga suku bunga bank, karena tingginya suku bunga bank akan berdampak pada berkurangnya minat investor untuk berinvestasi di Indonesia.

\section{Uji asumsi klasik}

\section{Uji multikolinearitas}

Uji multikolinearitas digunakan untuk melihat apakah didalam sebuah model regresi terdapat korelasi antar variabel bebas.Untuk mendeteksi adanya multikolinearitas dalam dilakukan pengujian dengan menggunakan VIF (Variance Inflantion Factors). 
Tabel 1. Hasil uji multikolinearitas

\begin{tabular}{cccc}
\hline Variable & Variance & VIF & VIF \\
\hline C & 57345038 & 38.01683 & NA \\
EX & 0.001907 & 20.59127 & 3.367358 \\
ULN & 0.001687 & 49.33007 & 5.727680 \\
NTB & 0.032436 & 4.037688 & 3.896037 \\
TML & 0.041637 & 8.612489 & 5.955475 \\
\hline
\end{tabular}

Sumber :Data diolah, 2019

Berdasarkan hasil uji diatas diperoleh hasil nilai VIF untuk variabel ekspor, utang luar negeri, neraca transaksi berjalan dan neraca transaksi modal masing-masing mendapatkan nilai 3,36, 5,72, 3,89, 5,95. Karena nilai VIF dari keempat variabel lebih kecil dari 10 maka dapat dinyatakan bahwa penelitian ini bebas dari gejala multikolinearitas.

\section{Uji heterokedasitas}

Untuk mengetahui untuk menguji apakah dalam regresi terjadi ketidaksamaan Uji ini digunakan untuk melihat ada atau tidaknya korelasi yang terjadi antara residual pada satu pengamatan dengan pengamatan lain pada model regresi.

Tabel 2. Uji heterokedastisitas

\begin{tabular}{llll}
\hline F-statistic & 1.002463 & Prob. F(4,15) & 0.4368 \\
Obs*R-squared & 4.218710 & Prob. Chi-Square(4) & 0.3772 \\
Scaled explained SS & 1.944292 & Prob. Chi-Square(4) & 0.7460 \\
\hline
\end{tabular}

Sumber : Data diolah, 2019

Berdasarkan hasil data yang telah di uji menggunakan uji breus, dapat diketahui $\mathrm{p}$ Value yang ditunjuk dengan nilai prob.Chi-Square(4) pada Obs*R-square yaitu sebesar 0,3772 . Dengan nilai $\mathrm{p}$ value $0,3772>0,05(\alpha=5 \%)$ maka $\mathrm{H}_{0}$ diterima yang berarti bahwa model regresi bersifat homokedastisitas atau dengan kata lain model regresi terbebas dari gejala heterokedastisitas.

\section{Uji autokorelitas}

Uji autokorelasi adalah sebuah analisis statistik yang dilakukan untuk mengetahui adakah korelasi variabel yang ada di dalam model prediksi dengan perubahan waktu.

Tabel 3. Uji autokorelasi

\begin{tabular}{llll}
\hline F-statistic & 0.384798 & Prob. F(2,13) & 0.6881 \\
Obs*R-squared & 1.117818 & Prob. Chi-Square(2) & 0.5718 \\
\hline
\end{tabular}

Sumber : Data diolah, 2019

Berdasarkan hasil regresi dapat diketahui bahwa nilai Prob.Chi-Square(2) yang perupakan nilai $\mathrm{p}$ value dari uji Breusch-Godfrey serial Correlation LM Test, yaitu sebesar $0,5718>0,05(\alpha=5 \%)$ maka $_{0}$ diterima atau dapat dikatakan bahwa dalam model ini tidak terdapat gejala autokorelasi.

\section{Uji normalitas}

Berdasarkan data dapat dilihat bahwa nilai prob. JArque-Bera hitung sebesar $0,797753>0,05$, maka dapat disimpulkan residualnya terdistribusi secara normal dan asumsi klasik tentang kenormalam telah terpenuhi. 
Tabel 4. Hasil regresi uji normalitas

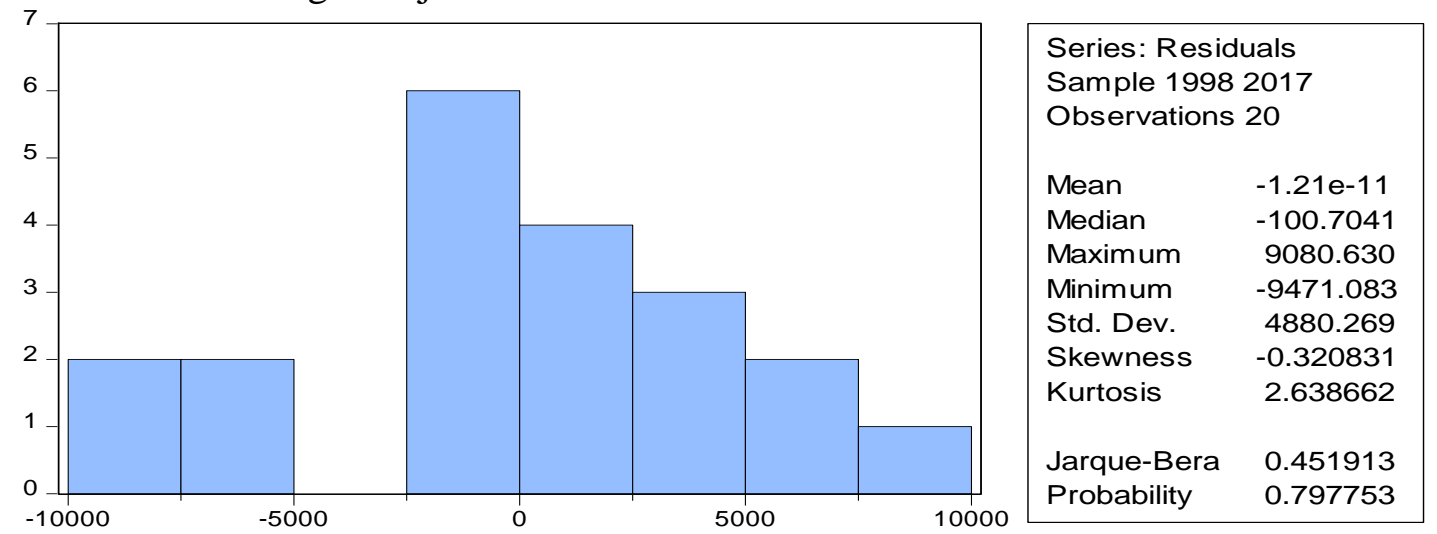

Sumber : Data diolah, 2019

\section{Pengujian secara parsial (Uji t)}

\section{Ekspor}

Berdasarkan hasil uji t-statistik diketahui bahwa variabel produk ekspor berpengauh signifikan terhadap cadangan devisa Indonesia dengan $\alpha=5 \%$. Hal ini ditunjukkan dengan nilai t-hitung $>$ nilai t-tabel yaitu sebesar 8,0786 > 1,7531 atau signifikan dengan probabilitas $0,0000<\alpha=5 \%$. Hasil regresi menunjukkan bahwa thitung > t-tabel maka $\mathrm{H}_{0}$ ditolak

\section{Utang luar negeri}

Berdasarkan hasil uji t-statistik diketahui bahwa variabel utang luar negeri berpengaruh signifikan terhadap cadangan devisa Indonesia. Hal ini ditunjukkan dengan nilai t-hitung $>$ nilai t-tabel sebesar 7,0422 > 1,7531 atau signifikan dengan probabilitas $0,0000<\alpha=5 \%$. Hasil regresi menunjukkan bahwa t-hitung $>$ t-tabel maka $\mathrm{H}_{0}$ ditolak.

\section{Neraca transaksi berjalan}

Berdasarkan hasil uji t-statistik diketahui bahwa variabel neraca transaksi berjalan berpengaruh signifikan terhadap cadangan devisa Indonesia. Hal ini ditunjukkan dengan nilai t-hitung > nilai t-tabel sebesar 3,2012 > 1,7531 atau signifikan dengan probabilitas $0,0059<\alpha=5 \%$. Hasil regresi menunjukkan bahwa t-hitung $>$ t-tabel maka $\mathrm{H}_{0}$ ditolak.

\section{Neraca transaksi modal}

Berdasarkan hasil uji t-statistik diketahui bahwa variabel neraca transaksi modal berpengaruh signifikan terhadap cadangan devisa Indonesia. Hal ini ditunjukkan dengan nilai t-hitung > nilai t-tabel sebesar 2,4194> 1,7531 atau signifikan dengan probabilitas $0,0287<\alpha=5 \%$. Hasil regresi menunjukkan bahwa t-hitung $>$ t-tabel maka $\mathrm{H}_{0}$ ditolak.

\section{Pengujian secara simultan (Uji F)}

Untuk memperoleh model regresi yang bersifat BLUE (Best, Linear, Unbiased Estimator), maka setiap variabel harus diuji dengan pengujian statistik. Pertama, variabel diuji dengan Uji F. Uji F digunakan untuk menunjukkan apakah keseluruhan variabel independen berpengaruh terhadap variabel dependen dengan menggunakan Level of significance 5\%. Criteria pengujiannya apabila Prob F. hitung $<\alpha$ berarti seluruh variabel independen berpengaruh secara signifikan terhadap variabel dependen dengan taraf signifikan tertentu. 
Berdasarkan hasil olahan data bahwa nilai Prob F. hitung $(0.000000)<\alpha(0.05)$. jadi dapat disimpulkan bahwa variabel independen secara bersama-sama berpengaruh terhadap variabel dependen.

\section{Koefesien determinasi $\left(\mathbf{R}^{2}\right)$}

Berdasarkan hasil perhitungan statistik diperoleh besarnya nilai koefesien determinan (R2) adalah 0,9837. Hal ini menunjukkan bahwa persentase pengaruh variabel independen (ekspor, utang luar negeri, neraca transaksi berjalan dan neraca transaksi modal) terhadap variabel dependen (cadangan devisa di Indonesia) adalah sebesar 98,37 persen. Artinya ekspor, utang luar negeri, neraca transaksi berjalan dan neraca transaksi modal memiliki persentase pengaruh terhadap cadangan devisa Indonesia sebesar 98,37 persen, sedangkan sisanya 1,63 persen dipengaruhi oleh variabel di luar model regresi yang diteliti.

\section{KESIMPULAN DAN SARAN}

\section{Kesimpulan}

Berdasarkan dari hasil yang telah didapat maka dapat diambil kesimpulan Perkembangan cadangan devisa Indonesia selama periode 1998-2017 mengalami fluktuasi dan cenderung meningkat, rata-rata perkembangan cadangan devisa Indonesia adalah 11,87 persen per tahun. Perkembangan ekspor Indonesia selama periode 1998-2017 mengalami fluktuasi, rata-rata perkembangannya adalah7,38 persen per tahun. Perkembangan utang luar negeri selama periode 1998-2017 mengalami fluktuasi dan rata-rata perkembangannya adalah 4,51 persen per tahun. Perkembangan neraca transaksi berjalan Indonesia selama periode 1998-2017 mengalami fluktuasi, rata-rata perkembanganya adalah 514,89 per tahun. Perkembangan neraca transaksi berjalan selama periode 1998-2017 mengalami fluktuasi, rata-rata perkembanganya adalah 66,92 persen per tahun. Faktor-faktor yang mempengaruhi cadangan devisa Indonesia berdasarkan hasil regresi linier berganda, variabel ekspor, utang luar negeri, neraca transaksi berjalan dan neraca transaksi modal berpengaruh positif dan signifikan terhadap cadangan devisa.

\section{Saran}

Untuk meningkatkan cadangan devisa Negara maka pemerintah harus meningkatkan ekspor yang lebih lagi meningkatkan kualitas dan kuantitas ekspor serta memanfaatkan utang luar negeri dengan lebih bijak lagi agar cadangan devisa di Negara Indonesia dapat menigkat lebih tinggi .

\section{DAFTAR PUSTAKA}

Asian Development Bank Key Indicaors for Asia and the Pasific. (2018). Data trasaksi transaksi berjalan, diakses dalam http//:www.adb.org/statistics. Tanggal 12 Januari 2017 WIB

Badan Pusat Statistik. (2018). Data nilai ekspor: Indikator ekonomi. BPS Indonesia: Jakarta.

Elmia, Putri Hanna, Toti Indrawati, Any Widayatsari. (2017). Pengaruh ekspor, penanaman modal asing dan utang luar negeri terhadap cadangan devisa di Indonesia. Skripsi Fakultas Ekonomi dan Bisnis. Universitas Riau

Gandhi, Dyah Virgoana. (2006). Pengelolaan cadangan devisa di Bank Indonesia. 
PPSK: Jakarta

Hariyani, Iswi dan serfianto. (2010). Buku pintar hukum bisnis pasar modal. Visimedia: Jakarta Selatan

Indrajaya, dan Putra IGB. (2013). Pengaruh tingkat inflasi, utang luar negeri dan suku bunga kredit terhadap cadangan devisa. Skripsi. Fakultas Ekonomi dan Bisnis. Universitas Udayana: Bali

Kuncoro, Mudjarat. 2009. Metode untuk bisnis dan ekonomi. Erlangga: Jakarta.

Lucyana Leonufna, dkk. (2016). Analisis pengaruh neraca pembayaran internasional terhadap tingkat kurs Rupiah/Dollar AS melaui cadangan devisa dalam sistem kurs mengambang bebas di Indonesia periode1998. Skripsi. Fakultas ekonomi dan bisnis Universitas Sam Ratulangi.

Priadi Asmanto, dan Sekar Suryandari. (2008). Cadangan devisa, financial deeping, dan stabilisasi nilai tukar riil rupiah akibat gejolak nilai tukar perdagangan. dalam buletin ekonomi moneter dan perbankan, Bank Indonesia, 11 (2):121153.

Sholihah,IM; \& S Syaparuddin, N Nurhayani. (2017).Analisis investasi sektor industri manufaktur, pengaruhnya terhadap pertumbuhan ekonomi dan penyerapan tenaga kerja di Indonesia, Jurnal Paradigma Ekonomika, 12 (1), 11-24

Sugiyono. (2015). Metode penelitian pendidikan (pendekatan kuantitatif, kualitatif dan $R \& D)$. Penerbit CV. Alfabeta: Bandung.

Tri Ellies Yulianti Suryaningsih, Roro (2007). Analisis faktor-faktor yang mempengaruhi cadangan devisa. Skripsi. Fakultas Ekonomi dan Bisnis. Universitas Sumatera Utara.

Umiyati,E. (2015).Pengaruh Hutang Luar Negeri Terhadap Pertumbuhan Ekonomi Indonesia, Thailand, Malaysia, Fhilipina, Vietnam Dan Burma Periode 1990201, Jurnal Paradigma Ekonomika, 10 (1)

Wira, Desmond. (2014). Analisis fundamental saham. Edisi Kedua. Exceed Books: Bandung 